Article

\title{
Participation and Sharing, or Peaceful Co-Existence? Visions of Integration among Muslims in Switzerland
}

\author{
Michael Nollert and Amir Sheikhzadegan * \\ Department of Social Sciences, University of Fribourg, 1700 Fribourg, Switzerland; E-Mails: michael.nollert@unifr.ch \\ (M.N.), amir.sheikhzadegan@unifr.ch (A.S.) \\ * Corresponding author
}

Submitted: 31 October 2015 | Accepted: 22 January 2016 | Published: 19 April 2016

\begin{abstract}
At least three traditions in sociological thought address the question of social inclusion. In the systems theory proposed by Luhmann, inclusion means that individuals are able to adapt and gain access to functional subsystems, such as the labor market or the welfare state. In the tradition of Simmel, social inclusion is seen as an outcome of "cross-cutting social circles". Both perspectives are addressed in Lockwood's distinction between social integration and system integration. Building on these theoretical traditions, the study proposes a typology of migrant integration in which inclusion requires a realization of both social and system integration. Against this theoretical background, the paper deals with the question of which kind of integration the Swiss Muslims strive for through civic engagement. Drawing on narrative autobiographical interviews, the study reveals two main tendencies among the studied Muslims. While some seek an opportunity to engage with people of other worldviews through civic engagement (social integration), others limit their civic engagement only to those religious communities that cultivate a strong collective Muslim identity, and reduce their contact with non-Muslims to a peaceful co-existence (system integration). The study also shows that these two attitudes are associated with two views on outgroup tolerance. While the advocates of social integration are for liberal tolerance, the supporters of system integration show tendency towards multicultural tolerance.
\end{abstract}

\section{Keywords}

coexistence; inclusion; Muslims; participation; segregation; social integration; Switzerland; systemic integration; voluntary associations

\section{Issue}

This article is part of the issue "Religious Diversity and Social Inclusion", edited by Gary Bouma (Monash University, Australia).

(C) 2016 by the authors; licensee Cogitatio (Lisbon, Portugal). This article is licensed under a Creative Commons Attribution 4.0 International License (CC BY).

\section{Introduction}

Without a doubt, one of the most common markers of social inclusion and exclusion throughout the history of mankind has been religious affiliation. Numerous examples of religious repression can be seen throughout history (Schneider, 2002). The traumatizing experiences of the World Wars and the Civil and Human Rights Movements in the second half of the 20th century have given rise, in Western countries, to extensive measures to institutionalize a culture of tolerance. However, with the rise of Islamic consciousness in the Islamic world and its expansion into Western countries in the last two decades there have been increasing calls to underscore the limits of tolerance. Thus, the integration of Muslims has acquired an unprecedented political relevance.

In the presented study, we do not analyze the objective inclusion of Muslims. Instead, we focus on one of the subjective aspects of integration, namely Muslims' normative views on their inclusion. We begin the paper with a survey of sociological theories of integration/inclusion as well as a review of the state of re- 
search. We then draw on narrative autobiographical interviews to analyze Swiss Muslims' views of integration and their preferred type of inclusion in Swiss society. Finally, we address the question of outgroup tolerance among the interviewees.

\section{Theoretical Framework and Research Questions}

We begin this section by discussing two traditions of sociological thought that have addressed the question of social inclusion. We then develop a conceptual framework merging both traditions. Finally, we outline our research questions.

\subsection{Inclusion through Access to Functional Subsystems}

Inclusion is a new and extensively discussed concept in modern systems theories. Lockwood (1964) distinguishes between social integration, the interaction between individuals, and system integration, the interaction between institutions. Luhmann's systems theory (1997) differs from Lockwood's typology as it first replaces the concept of system integration with that of integration. In addition, he argues that social integration should no longer refer to the relationships between human individuals but to the communicative relationship between people and functional subsystems. As a result, Luhmann (1997) proposes a substitution of Lockwood's concept of social integration with the notion of inclusion/exclusion. Hence, people who lack of civil, political and social rights (Marshall, 1950), such as the residents of the Brazilian Favelas, are more or less excluded (see also Farzin, 2006; Stichweh, 2005). In summary: Luhmann's concept of social inclusion highlights individuals' ability to adapt to and access functional subsystems. Of particular relevance for Luhmann is the inclusive function of the welfare state in providing all individuals with similar life opportunities and social security. However, Kronauer (2010) has argued that inclusion goes beyond material subsistence and poverty containment to also include social interaction between individuals and groups. This position is advocated in the second tradition outlined in the following section.

\subsection{Inclusion by Bridging Networking}

Even though Simmel is rarely discussed as an integration theorist, his reflections on modernity can also be read as an implicit theory of integration. According to Simmel (1908a), modern societies are characterized by the "intersection of social circles", as individuals go beyond their original social circles to join new social networks. Although a modern person continues to be a member of his/her family, he/she also establishes contacts with other social circles, including voluntary associations. As he/she stands at the intersection of the so- cial circles he/she is a member of, he/she develops an individual identity distinct from that of other individuals. Individualization is, therefore, the result of the accumulation of affiliations with different social circles (see also Nollert, 2010).

While the individualization process increases freedom of action, it also creates uncertainty. A modern person suffers from similar unease as Park's Marginal Man does: "One who is poised in psychological uncertainty between two (or more) social worlds, reflecting in his soul the discords and harmonies, repulsions and attractions of these worlds" (Stonequist, 1937/1961, p. 8). Therefore, it is unsurprising that people who engage in cross-cutting social circles sometimes lack a sense of community and suffer from a resulting attachment deficit (Nollert, 2014).

Instead of having a dominant or solitary identity (Sen, 2006), modern individuals develop cross-cutting identities (Bell, 1980, p. 243), with the consequence that they do not a priori know which part of their identity is salient. Modern individuals are often faced with loyalty conflicts. This is a result of being constantly confronted with divergent, if not contradicting, expectations from the circles they are affiliated with. In short, modern people are faced with a variety of intra-role and inter-role conflicts (Dahrendorf, 2006).

Although affiliation with cross-cutting social circles can cause much distress at the intrapersonal level, in the realm of social relations, it can also be a source of social integration. Thus, as an individual's attachment to his/her circle of origin is lessened and he/she is partially integrated into new social circles, he/she becomes more open-minded and his/her prejudice is reduced. Quoting from Simmel's (1908b) essay "The Stranger", Park describes the Marginal Man as follows: "He is the freer one, practically and theoretically. He views his relation to others with less prejudice. He submits them to more general, more objective standards, and he is not confined in his action by custom, piety, or precedents" (Park, 1928, p. 888).

Finally, one has to take into consideration that increasing and intensifying social contacts contribute to the erosion of homogeneous group identities. Welsch (2009), for instance, has argued that intercultural contacts ultimately result in a vanishing of cultural differences und the emergence of transcultural individuals with hybrid identities.

To sum up, social integration requires that individuals are not restricted in their social contacts by normatively homogeneous communities with rigorous boundaries. Thus, in line with Putnam's social capital theory (Narayan, 1999; Putnam, 2000), it can be argued that social integration requires social ties that would build bridges between social circles. This notion is also in line with Berry (1997)'s concept of integration in his typology of acculturation strategies, according to which integration goes beyond a mere side-by-side existence 
of separate, normatively homogeneous social circles to also include interactions between individuals and groups.

\subsection{Inclusion as Realization of System and Social Integration}

An encompassing definition of social inclusion can be derived from Lockwood's (1964) distinction between social and system integration. Lockwood defines social integration as orderly or conflictual relationships between actors, and system integration as orderly or conflictual relationships between the parts of a social system. One aspect, namely social relations, is the focus of network approaches. The other aspect, the relations between institutions, is the focal point of systems theories. Thus, on one hand, network approaches underscore the engagement of individuals in social groups alien to their ingroups. On the other hand, systems theories emphasize the congruency and coordination between markets, businesses, governmental institutions, and churches.

While systems theory is often criticized for neglecting social relations (Granovetter, 1985), the network perspective is reprehended for disregarding the impact of institutions (Brinton \& Nee, 1998). In fact, social networks and associations are not sufficiently integrated unless they are embedded in a variety of political, economic and cultural institutions.

In our view, a thorough integration requires both system and social integration. Moreover, we regard system integration as something more than a mere coordination between institutions. In line with Luhmann's concept of inclusion, we argue that individuals also need access to these institutions in general, and to the labor market and welfare state in particular. In other words, individuals have to be "anonymously" integrated into the labor market and, if unemployed, sick, or old, into welfare institutions that guarantee their maintenance.

Our typology (see Figure 1) is based on two dimensions. From the network perspective, integration is realized when people maintain face-to-face contacts with a broad range of people (social integration). In contrast, systems theories regard integration as harmony between institutions as well as people's access to these institutions (system integration). From the intersection of these two dimensions, there emerge four types of integration: inclusion, interaction, co-existence, and exclusion.

Inclusion refers to a situation in which both system and social integration occur. Therefore, people can only be regarded as included if they are endowed civil, political, and social rights (Marshall, 1950), and if they can establish crosscutting social ties (Kronauer, 2010). This premise is compatible with Bourdieu's theory of capital (Bourdieu, 1983), according to which social inclusion can only be achieved if people have access to institutional resources, and that these resources are often made available through economic and cultural capital, or when social capital is generated through active participation in social networks. In the opposite case, exclusion happens when both social and system integration are absent. Interaction refers to a situation in which individuals (or groups) have social contacts to one another, but lack universal access to the core institutions of society. Extreme examples of this type of integration are slaves, child laborers, or illegal workers. Co-existence can be defined as system integration without bridging social ties. This type of integration can

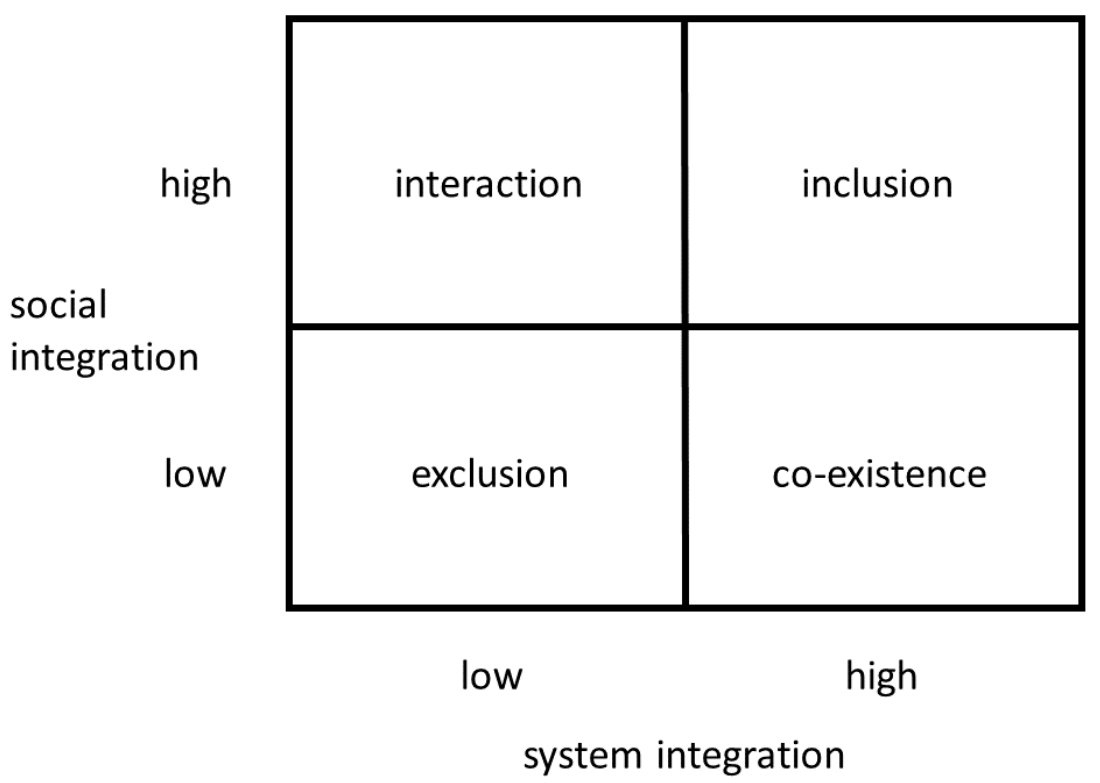

Figure 1. Social inclusion as realization of system and social integration. 
even be, paradoxically enough, achieved in a highly segregated society, provided that the labor markets provide jobs and the state guarantees for welfare and equal rights. Hence, co-existence implies a segregationist multiculturalism, or, as Sen (2006) has put it, a plural monoculturalism. This is for instance the case when a minority prevents its members from contacting with the dominant population and strives instead for a segregated lifestyle, albeit in peaceful co-existence with other social groups. Co-existence is also compatible with a neo-liberal regime. In the United Kingdom, for instance, the co-existence model was supported for a long time by political neoliberalism. Thus, the cultural minorities were allowed to experience their own lifestyles, so long as they minimized their claims on social welfare. However, because this kind of co-existence can transform into spatial segregation, it has lost political support in the last few decades (Kivisto, 2013).

\subsection{Research Questions}

Our concept of social inclusion assumes, in line with Lockwood, a positive coordination of functional subsystems, and, in line with Luhmann, access to the core institutions of society. Moreover, drawing on Putnam's concept of bridging social ties, we assume that inclusion requires people to have cross-cutting group memberships.

In the public debate on integration of migrants, religious affiliation is of special interest. This is simply because orthodox religious leaders usually demand from their followers strict adherence to specific normative standards and restricted contact with "non-believers". In this sense, members of religious minorities are constantly exposed to psychic tensions, having to choose between retreating into the religious community and being socially open. Indeed, both alternatives pose their own risks. While retreat often leads to isolation, stigmatization, and orthodoxy, becoming open might lead to a loss of identity (see Coser, 1956).

Regarding the foregone reflections, the paper deals with following questions. First, it explores the question of which kind of integration the Swiss Muslims strive for through civic engagement, and which kind of normative positions they advocate when it comes to their integration into Swiss society. Second, we explore the question of the attitude of the interviewees towards outgroup tolerance.

\section{State of Research}

So far, sociological studies on the subjective dimension of migrants' integration have been mainly focused on the views and perceptions of the native population. In contrast, the views of Muslims on the topic of integration are widely under-researched. Studies based on World Values Surveys, as well as European Values Sur- veys, usually focus on the attitudes of natives towards Muslims, thus neglecting value orientations of Muslims (an exception is Davidov, Schmidt, \& Schwartz, 2009), as well as their attitude towards integration. However, some studies address the extent of tolerance among different religious communities including Muslims. For instance, the studies by Inglehart and Norris (2012) and Tausch (2014b, 2015) based on PEW-data, indicate that the tolerance of Muslims varies widely between countries. Tausch and Karoui (2011) and Tausch (2014a) also show that the Salafist position is marginal in Europe. Miligan, Andersen and Brym (2014) have documented that tolerance within Europe varies not only between countries but also between Muslims and Christians and between practicing and non-practicing believers. Finally, drawing on a survey of Muslims of Turkish and Moroccan origin in six European countries, Koopmans (2015) has argued that religious fundamentalist attitudes among Muslims are more widespread than among native Christians.

However, the mentioned studies and data from the European and World Values Studies are of limited value for our research as they do not analyze behavior, and do not inform what integration means to Muslims and which type of integration the latter prefer. Furthermore, the studies also presuppose a stability of values over the course of life, while our qualitative research suggests, in line with Park (1928), that values might change as a result of migration and interaction with the native population (see also Rudnev, 2013).

Closer to our research question is the study carried out by Van Oudenhoven, Prins and Buunk (1998). The authors analyzed the adaption strategies of Moroccan and Turkish immigrants in the Netherlands, and compared them with members of the Dutch majority. They identified four adaption strategies: assimilation (original culture is considered unimportant, whereas contact with the majority is regarded as important), integration (both the original culture and contact with the majority are regarded as important), separation (original culture is considered important, whereas contact with the majority is not), and marginalization (both the original culture and contact with the majority are considered unimportant). Most Moroccans and Turks preferred integration, whereas the Dutch had positive attitudes toward both assimilation and integration. However, the Dutch believed that separation would be the strategy chosen most frequently by the immigrants.

According to Brettfeld and Wetzels (2007), who combined qualitative interviews and a survey of Muslims in Germany, most Muslims (more than 70\%) argued against assimilation. However, more than $45 \%$ also thought that foreigners should adapt to the native culture, and only $9 \%$ favored separation. The survey also showed that segregation is mostly favored by fundamentalist and orthodox Muslims. A small minority of the fundamentalists also supported religiously moti- 
vated violence, disliked democracy, and indicated intolerance. Moreover, the authors emphasized that the combination of beliefs of segregation and radicalism among these Muslims closely resembles the position of the Neo-Nazis.

A telephone survey of 1350 young Muslims and non-Muslims in Germany (Frindte, Boehnke, Kreikenborn, \& Wagner, 2012) indicated that the two studied groups have similar positions on integration. The findings suggest that the most radical views (antiSemitism, authoritarianism, religious fundamentalism) are supported by a sub-group of non-German Muslims (i.e., Muslims without German citizenship), who also favor separation. The non-German Muslims who favored integration were those who had more social contacts with Germans. Neither German nor non-German Muslims favored assimilation.

In their interviews with 21 Muslim intellectuals or those active in public or community debates, Modood and Ahmad (2007) examined what these Muslims think about multiculturalism. The analysis shows that the respondents advocate multiculturalism, as long as it includes faith as a dimension of difference. In most of the other aspects of the multicultural ideal, the respondents seemed to share the views of non-Muslim British multiculturalists. Yet some of the interviewees believed that Islam's multicultural concepts are superior to the offers of any other faith or civilization. This view was advocated by those who are specialized in engaging with contemporary Western discourses rather than by religious authorities.

Finally, the qualitative studies of Yasmeen (2014) and Duderija (2014) both underline that certain Muslim minorities, in particular Salafists, cherish exclusionary practices. On one hand, they develop a sense of superiority towards the religiously other and therefore have little interest in social interaction with non-Muslims. On the other hand, they also take an exclusionary stance towards non-Salafi Muslims and Muslim women.

In summary, the research on integration views and preferences of Muslims in Europe suggests that a large majority of them favor a combination of conservation of their original culture and partial assimilation. This also includes making social contacts with the dominant population. Only a very small minority prefers separation while advocating radical worldviews and intolerance.

\section{Methods and Data}

\subsection{Collecting Data}

Regarding methodology, this study was based on a combination of document analysis, participatory observation, semi-structured interviews, and narrative autobiographical interviews. The document analysis was used to investigate the content of the websites, bylaws, communiqués, and other documents of the selected associations. Insight into the ways in which association members negotiate their collective identities was gained by participatory observation. Semistructured interviews were conducted with association principals (President, Vice-President, or Imam), who acted as gatekeepers for us. The goal of these interviews was to collect information on the history, objectives, and internal relations of each association. The semi-structured interviews also helped to establish the trust of the gatekeepers.

Narrative autobiographical interviews, the main data-gathering method of the study, were conducted in order to gain insight into the narrative identities of the selected active members of the associations. In line with Lucius-Hoene (2000), narrative identity was understood as "a situated, pragmatic, autoepistemic and interactive activity drawing on culturally transmitted narrative conventions which is performed within the research context".

The transcribed interviews were analyzed according to the so-called "reconstruction of narrative identity" method developed by Lucius-Hoene and Deppermann (2004). Since this method is relatively new, its fundamentals are described below. Prior to this description, a brief explanation of the three dimensions of narrative identity (temporal, social, and self-referential) will be given, which the authors have accorded a prominent position in their evaluation.

The temporal dimension primarily relates to the question of how the story is structured in terms of time. Narrative autobiographical constructions include justifications and explanations for how the self became what it is. Thus, they also form the basis for orientation of actions and plans for the future (Lucius-Hoene \& Deppermann, 2004, p. 57). Also important to the temporal dimension is the question of agency; one would like to establish if the narrator presents him/herself as an active and acting subject in his/her narration, or as the passive object of forces and powers that he/she cannot control.

The social dimension is concerned with the following questions:

- Positioning: What roles does he/she assign to him/herself and his/her interaction partners (both in the narrated episodes as well as in the interview situation)?

-World construction (Weltkonstruktion): How does he/she describe the physical and social environment and the general conditions of his/her stories?

- Narrative conventions: To which culturally transmitted narrative conventions does he/she have recourse in his/her narration?

The self-referential dimension is about the self- 
reflections of the narrator. The following questions are of particular interest:

-What characteristics does the narrator ascribe to him/herself?

-Which attachments are thus expressed?

- How does his/her "theory of self" express itself? What assumptions about him/herself does he/she make as an "expert on his/her own ego"?

-What discoveries does the narrator make about $\mathrm{him} /$ herself during the narration (autoepistemic processes)?

\subsection{The Analysis Procedure}

Once the interviews are transcribed, one starts with the analysis of the collected texts. The reconstruction of narrative identity consists of three main steps: rough macroscopic analysis, detailed microscopic analysis, and reconstruction of the case structure.

- In the macroscopic structural analysis, one attempts to reconstruct how the narrator structured his/her story chronologically and thematically.

- A detailed microscopic analysis is a sequential analysis of a selection of interview passages that appear particularly relevant to the enquiry. Here, "general heuristics" are analyzed first ("Questions regarding the data": What is shown; how, why, and why thus and not otherwise?). Thereafter, one tries to find clues about the three dimensions of narrative identity in the respective passage. Due to the fact that narrative identity, by definition, represents a linguistic performance, one should also employ a series of linguistic and communicative methods in undertaking such analyses (see Lucius-Hoene \& Deppermann, 2004, chapter 9).

- Once the analyses on the macro and micro levels are completed, one attempts to assemble the many fragments into a case structure.

For the sake of brevity, in this article we present only an abridged report of our analyses.

\subsection{Sampling}

Although our premises apply to all people, for the following reasons we focused our project on Muslims in Switzerland. The mass media in Switzerland and wider Europe often define Muslims as members of a minority that is difficult to integrate. They therefore face prejudice and discrimination (Cesari, 2004; Kivisto, 2013; Kühnel \& Leibold, 2007; Sheridan, 2006; Stolz, 2005), which exacerbates their opportunities and willingness to establish and maintain contact with other communities. Moreover, many migrants are from countries with weak civil society structures (Gellner, 1994) and are therefore likely to have little experience with voluntary organizations (Amacker \& Budowski, 2009). Finally, they are sometimes drawn into the maelstrom of religiously inspired anti-systemic movements in the Islamic world. This involvement may manifest itself as alienation from the local civil society. For these particular reasons, it seemed all the more interesting to examine whether Muslims' civic engagement has a significant impact on their attitude toward outgroups and toward the whole society.

The study was based on purposeful, two-step sampling. Firstly, eight Muslim voluntary organizations in Switzerland were selected, some with an outspoken bridging character, others with a pronounced bonding culture. Secondly, 26 members of the selected organizations (16 men and 10 women) were chosen for narrative autobiographical interviews.

\section{Integration from the Point of View of Muslims: Two Prototypical Cases}

As the narratives we analyzed in our research project corresponded to either the type inclusion or the type co-existence, with nobody matching any of the other two types, in this section we deliver two prototypes that almost perfectly represent the types inclusion and co-existence. In section six we refer to other autobiographical narratives of our project to underpin the findings presented in the two prototypes.

\subsection{Case Study 1: Akbar}

Along with his parents, Akbar (52) arrives in Switzerland from Pakistan at the age of two. His father, a lawyer and religious scholar, has the task of looking after the affairs of the Ahmadiyya community, which represents a minority within Sunni Islam, in the Diaspora. Akbar is sent to an international boarding school where he comes into contact with a variety of nationalities and religions. After graduation, he studies linguistics and graduates with a degree in German literature. He is self-employed, and through his office, he coordinates teaching assignments, translations, consultations, and volunteer activities. He works both as a high school teacher and as a lecturer in intercultural studies at a technical college. Although Akbar is very active professionally, volunteer activities take up much of his time. He maintains several charitable projects, holds a post of responsibility in a mosque organization, and is very active in the Swiss Green Party, a secular leftist party. He is also committed to development aid, plays an active role in local politics, and is active in associations for the integration of marginalized people, as well as intercultural dialogue. Akbar is married and has two children. 
Akbar's worldview points to a carefree childhood in a social and missionary upper-middle class environment. When asked how he became the man he is today, Akbar replies:

"It was primarily my parents who pointed me in this direction. I did, as I said, grow up in the mosque. And that's a mosque to which African kings had come; Muhammad Ali had come, the boxer. Presidents of different countries had come, but also the tramp, the poor man from the street. Even a Swiss tramp. My parents took equal care of everybody. I cannot remember any man ever coming to my parents and saying that he was hungry, or needed somewhere to stay the night, or that he was cold, that they would not have taken care of. And that, of course, is something that has affected me very much, you know? And everything else is in consequence of the fact that my parents have influenced me thus, you know? I think that has been the key point. And then, of course, there was the international school. There [we talked about everything, for instance] the Israeli-Palestinian conflict. And there were Israelis at the school, and there were Arabs. And we discussed things all night long."

The experiences of his formative years affect him to the present day. As a humanistic understanding of Islam dominates his family's culture, being helpful and charitable is prominent in Akbar's sense of self.

"Education is my identity, women's rights are my identity, these I promote most of the time, you see? Or, to put it roughly, standing up for people who are in distress or who are underprivileged. It does not matter which country they are in. I campaign for such people in Pakistan, but I equally campaign for such people in Switzerland. This may be my identity or it is identity-forming."

Given this sense of self, Akbar's numerous civic activities are not surprising. In this respect, a high degree of continuity can be observed with respect to the temporal dimension of his narrative identity. This is particularly noticeable in his identification with his lifework-a school project for marginalized girls in Pakistan-because the project is a realization of his childhood dream:

"There [at school] when I was fourteen, I decided this, and I typed this on my first electric typewriter which I had bought or got as a present, that later, when I had grown up, I myself would build such a boarding school, though not for the richest people, but for the poorest, you know?....And I have now made this a reality."
As the first generation of female students approaches the end of high school, a college with a two-year degree course is being planned. It is with pride that Akbar points out that about half of the 200 girls enrolled come from Christian families, who often live a marginalized existence in Pakistan. Thus, he wants to counter the widespread notion that Muslims only support their co-religionists.

\begin{abstract}
"The important point is that all of these girls attend our school without paying fees. They belong to the lower class. These are [also] people who are underprivileged because of their religious affiliationthey are Christians. We have a disproportionate number of Christians, considering that we have roughly fifty percent Muslim girls and fifty percent Christians, you know?"
\end{abstract}

Akbar's strong inclination toward charitable activities is in line with the humanitarian objective of his religious community. However, this does not mean that he identifies exclusively with his religion. Rather, he identifies with his many activities and memberships, which contribute to a complex and varied social identity.

\subsection{Case Study 2: Urs}

In his autobiographical narration, Urs (30) depicts a difficult adolescence. The reason seems to lie within his family. His mother divorces his father, who is struggling with addiction problems. She places Urs in the care of a foster family and emigrates. Urs finds support in the new family, whose members are deeply religious. His foster parents are puritanical Protestants and followers of a free church. He enjoys a warm family life and practices Christian rituals with the family. For a young man who was raised far from religion, his new life as a disciplined, practicing Christian is a fascinating experience. After a while, Urs leaves the family and moves abroad to be with his mother. The familial, religious life of the young teen now gives way to a much more permissive adolescent life.

Upon his return to Switzerland, Urs initially joins a strongly patriotic, conservative political movement. Later, he takes an interest in the Palestine question. In particular, the bombing of an airport in the occupied territories by the Israeli army seems to have had a drastic effect on him ("I lost it completely") - the more so, as the airport was built with the funds of SDC (The Swiss Agency for Development and Cooperation). He is now committed to the Palestinian cause. During a short stay in the Gaza Strip, he becomes fascinated by the hospitality of the Palestinians, their human warmth, and their supportive communal life.

He attributes the hospitality of the Palestinians to Islamic principles. It also excites him that Islam is a vibrant, community-based religion that permeates the 
everyday life of the faithful. His adoption of Islam is made easier by the fact that he did not give up his faith in God. At age 21, he converts to Islam.

In the foreground of Urs' conversion to Islam, we find first of all the re-socialization of a young person who longs for the warmth of a community (Bauman, 2000). This also explains his earlier involvement in a patriotically oriented political movement. In addition, his longing for a "normative edifice", which would give him guidance, testifies to Durkheim's understanding of an anomic state before conversion. In this respect, it is also possible here to speak of a methodizing of life (Weber, 1905/2002; Wohlrab-Sahr, 1999) as a result of conversion.

After conversion, Urs becomes a strictly practicing Muslim who places religious ritual at the center of his life. Henceforth, he dedicates himself to the cause of Muslims in Switzerland as well as abroad.

"I really want to practice my faith consistently and don't want it pushed into a corner again and again through argument and discussion about the centrality of Western modernity. If something has to be at the center, then, conversely, I want religion, faith in God, and religious rituals to be at the center and the world to be organized around them. And this I thought I had found in Islam at the time, hadn't I? Yes, this is how I became the person I am today."

It is in this association that Urs finally finds the stability, nest warmth, and sense of family he has been missing for so many years.

"The stability and constancy of an association, an organization, I only found here, in this association. At the same time, it has become a kind of center of life for us, has it not?"

When questioned if he had any sympathy with a particular political party or identified with a specific political orientation beyond his commitment to Islam, Urs gave this answer.

"That's for me...how should I say? As already mentioned, my identity is Islam, and from this life-order perspective [Lebensordnungsperspektive] I am a little bit eclectic, when it comes to voting for a party.

[...]

[Moreover,] I simply couldn't be in a party at all. That's the reason. However, I think, nowadays many people believe that this political system is just too narrow."

What Urs strives for is the greatest possible autonomy of the Muslim community and its freedom to live up to its religious code. At the same time, he attaches great importance to the recognition of Islam and its ac- ceptance as "normal" by the host society.

"We see ourselves as a family with an idea. And the idea is that Islam gets naturalized in Switzerland. That one day the Muslims can say: We live here in Switzerland, not as guests, but as Muslims who are a recognized part of Switzerland.

[...]

Actually, we want to do away with the Muslim migrants' guest mentality that has prevailed up to now....We should not always ask for whatever we need. We should just take it. We should, for example, be able to build a mosque without having to beg society for a friendly gesture and without having to bow our heads. We should simply build it, as soon as we have the money for it and we have sought permission. This is more or less the idea, that we have a normalization discourse and try to normalize Islam in Switzerland, to normalize it according to the meaning of Jürgen Link's normalization theory."

By being a "normal" part of Swiss society, Urs means that practicing Muslims should be allowed to live up to their religious code of conduct in the public sphere without being stigmatized for it. In order to demonstrate this, he mentions the example of the normalization of homosexuality in Switzerland.

\footnotetext{
"We remember, for instance, the homosexuals here in Switzerland. They too had...let's say in the 1950s, they could have been arrested if they outed themselves as homosexuals. Today, they are even allowed to marry, as homosexuals, aren't they? So we want to impose [on] society a similar normalization discourse, in the sense of 'We are normal. What we do here is normal. We belong to Switzerland', and that the tolerance imperative, the freedom rights, and the plural, democratic system of Switzerland oblige the society to accept this normality."
}

"Normal" does not primarily mean that Muslims have the same civic, political, and social rights. Rather, it implies a peaceful co-existence between Muslims and non-Muslims. Consequently, his association is not looking for interaction with the dominant population but separation from it. It attaches importance to possessing the right to an orthodox education of children, as well as segregated sports (both after gender and faith) and separated burial grounds. Finally, it denounces Muslims who campaign for the modernization of Islam.

\section{Discussion}

As typical cases of the two main groups of interview- 
ees, Akbar and Urs have contrasting views on integration.

Akbar is engaged in numerous volunteer associations beyond the cultural/religious community he belongs to. Islam is only one part among others in his identity, and he shows strong identification with the many social projects he is engaged in. In Akbar's narration, neither excessive identification with an ingroup nor hateful demarcation against any outgroups can be noticed. It is only from the jihadists that Akbar distances himself. The active role he plays in the secular and left Green Party is also an indication of his deep concern for social welfare issues. Therefore, it can be said that he is in favor of social integration.

Urs, on the other hand, prefers co-existence. He is exclusively engaged in the Islamic organization which he co-founded. His most important cause is the equal treatment of Islam in Switzerland, achieving maximum autonomy for the community of practicing Muslims, and the separation of Muslims from non-Muslims. He relies on the democratic tradition and the liberal values of Swiss society to justify the demand of his organization for tolerance vis-à-vis practicing Muslims. His primary concern is the tolerance of his ingroup by outgroups and not vice versa. During the entirety of the interview he does not mention any other social groups that suffer from stigmatization. When he refers to the successful campaign of the Swiss homosexuals in "normalizing" their sexual orientation, he does so to demonstrate the strategy of his association. Any expression of sympathy that goes beyond this cognitive level is absent from his assertions.

His devotion to Islam and the Muslim community prevents him from engaging in secular organizations, such as trade unions, political parties, or neighborhood associations, in which religious affiliation is expected to be a personal, private issue. His position can therefore be interpreted as advocacy for high systemic integration but low overall social integration. According to our typology, he is primarily interested in a peaceful coexistence between the native population and Muslims. Thus, he demands the integration of Islam, while rejecting the requirement that Muslims should engage with the non-Muslim population of Switzerland.

As for the second focal point of the study, Akbar and Urs also represent two distinct types of outgroup tolerance. From a libertarian perspective, Urs demands that the Swiss native population should respect and even guarantee the autonomy of his ingroup and should not interfere in its internal affairs, thus allowing it to live up to its specific norms and rituals in its exclusive spaces. This attitude is based on putting collective rights of social groups over the rights of individuals. Hence, we suggest labeling this kind of attitude as multicultural tolerance.

In Akbar's narrative, there is no explicit reference to tolerance. However, his pride in being open to the views of different social groups (for instance the views of both Israeli and Arab students on the Palestinian conflict at the boarding school), his sensitivity towards human rights issues and his "standing up for people who are in distress or who are underprivileged" are all indicative of his openness, sympathy and care for marginalized people beyond their group attachments. Such an attitude is based on putting the rights of individuals over the collective rights of social groups. Hence, we suggest labeling such an attitude as liberal tolerance.

As already mentioned, Urs and Akbar represent two main groups among our interviewees. While the one group favors system integration as well as multicultural tolerance, the other group is supportive of both social integration and liberal tolerance (for a detailed description of this typology see Nollert \& Sheikhzadegan, 2014, 2016). Furthermore, we could identify two subgroups among the latter. While one group showed clear shift towards liberal tolerance through civic engagement, the members of the other group were raised as tolerant individuals in the first place. Taking Akbar's childhood into consideration, it is fair to characterize him as a person whose tolerance was due primarily to his socialization in a tolerant environment.

The insight won by the above-discussed narratives can be well supported by other narratives. For the sake of brevity, we focus on the question of tolerance.

Respondents like Akbar have generally numerous civic engagements, a relatively complex social identity, and are supportive of liberal tolerance. For instance, Bekim, a 55-year old Kosovan migrant (who was also a trade-unionist) told us that in the course of his commitment to diverse volunteer associations, he has overcome both his distaste for religion and homosexuals. Similarly, Aras, a 58-year old Marxist-oriented trade-unionist of Turkish origin, developed a greater tolerance towards right-wing religious workers. A Syrian woman reported how civic engagement in her neighborhood helped her to overcome her social isolation as a housewife, to establish contact with people of different ethnic and social origins, and to restore her self-image as a socially active person. Regaining her selfconsciousness, she co-founded an association of Arab women as well as a "roundtable of religious dialog".

Conversely, orthodox Muslims such as Urs, who are exclusively committed to a single association, tend to grow in distance from other social circles, including their original peer groups, and are generally supportive of multicultural tolerance. Mehmet (36), the son of a Turkish labor migrant family joined the organization of Urs after experiencing a spiritual transformation. Since then, he sees his religion with new eyes. He uses all his leisure time to empower practicing Muslims and to enhance their ability to live up to their faith. Sara (22), the daughter of a Kosovan labor migrant family, had to endure bitter experiences of discrimination because of her head scarf. She joined the same organization in or- 
der to participate in its collective action to protect the rights of practicing Muslims.

Indeed, the notion that membership in different social circles promotes tolerance is not new. For instance, de Tocqueville has underscored the role of voluntary associations in promoting mutual understanding and cooperation. Durkheim (1897/1951), has argued that in modern societies, neither the family, the religion, nor the state have an integrative function in society (see also Pescosolido \& Georgianna, 1989). According to him, the only source of integration is voluntary association because social circles crosslink their members and curb any excessive emotions within in the group. Moreover, Allport (1954) has postulated the contact hypothesis, according to which, people who belong to a variety of social groups have more contacts and, therefore, tend not only to overcome their stereotypes and prejudices, but to also develop more generalized tolerance (see also Frölund Thomsen, 2012). Finally, Roccas and Brewer (2002) have argued that people with complex social identities are more open to change and more tolerant of otherness: "In sum, both cognitive and motivational factors lead us to predict that complex social identities will be associated with reduced ingroup favoritism and increased tolerance and positivity toward outgroups in general" (Roccas \& Brewer, 2002, p. 102; see also Brewer \& Pierce, 2005).

\section{Conclusions}

The research project outlined in this article focused on the subjective dimension of integration. It did this through investigating the views of Muslims in Switzerland on the optimal way of their integration into Swiss society. The autobiographical narratives we analyzed suggest that Muslims in Switzerland prefer one of two options. The preferences are either a combination of social and system integration (social inclusion) or a peaceful co-existence that would provide equal rights to Muslims, but also foster segregation of Muslims from non-Muslims. Accordingly, we found two distinct types of outgroup tolerance. The interviewees who supported social inclusion showed a liberal tolerance, based on the primacy of individual over collective rights. On the other hand, the interviewees who advocated peaceful co-existence between autonomous faith communities showed a multiculturalist tolerance, which means that they were more concerned about the collective rights of the communities than the rights of individual members of social groups.

Although only two prototypical cases are discussed here, our research has important implications for the future research. Firstly, it underlines the multidimensionality of the term integration. Secondly, it shows the linkages between the attitude towards integration and the outgroup tolerance. Thirdly and finally, it shows the importance of biography and habitus for the development of outgroup tolerance and of personal attitude towards integration.

\section{Acknowledgements}

This research with the German title "Freiwillige Assoziationen, multiple Identitäten und Toleranz. Eine Rekonstruktion narrativer Identitäten von Assoziationsmitgliedern mit besonderer Berücksichtigung von Musliminnen in der Schweiz" was supported by the Swiss National Science Foundation (grant no. 100017_134841).

\section{Conflict of Interests}

The authors declare no conflict of interests.

\section{References}

Allport, G. W. (1954). The nature of prejudice. Reading, MA: Addison-Wesley.

Amacker, M., \& Budowski, M. (2009). Exclusión social y sociedades paralelas: ¿Círculos sociales disyuntivos inclusivos y exclusivos? In J. F. Tezanos (Ed.), Tendencias sociales. Juventud y exclusión social (pp. 51-88). Madrid, Spain: Editorial Sistema.

Bauman, Z. (2000). Community: Seeking safety in an insecure world. Oxford, UK: Polity Press.

Bell, D. (1980). The winding passage: Essays and sociological journeys 1960-1980. Cambridge, MA: Abt Books.

Berry, J. (1997). Immigration, acculturation, and adaption. Applied Psychology: An International Review, 46(1), 5-68.

Bourdieu, P. (1983). Forms of capital. In J. C. Richards (Ed.), Handbook of theory and research for the sociology of education (pp. 241-285). New York: Greenwood Press.

Brettfeld, K., \& Wetzels, P. (2007). Muslime in Deutschland: Integration, Integrationsbarrieren, Religion sowie Einstellungen zu Demokratie, Rechtsstaat und politisch-religiös motivierter Gewalt. Retrieved from http://www.islamdebatte.de/studien/2007studien/brettfeld-katrin-wetzels-peter-2007muslime-in-deutschland

Brewer, M. B., \& Pierce, K. P. (2005). Social identity, complexity and out-group tolerance. Personality and Social Psychology Bulletin, 31(3), 428-437.

Brinton, M. C., \& Nee, V. (1998). The new institutionalism in sociology. New York: Russell Sage Foundation.

Cesari, J. (2004). When Islam and democracy meet. New York: Palgrave.

Coser, L. A. (1956). The functions of social conflict. Glencoe, IL: Free Press.

Dahrendorf, R. (2006). Homo sociologicus. Ein Versuch zur Geschichte, Bedeutung und Kritik der Kategorie der sozialen Rolle. Wiesbaden, Germany: VS. 
Davidov, E., Schmidt, P., \& Schwartz, H. (2009). Value orientations of Muslims in Europe. Paper presented at the 3rd ESRA Conference, Warsaw, June/July 2009.

Duderija, A. (2014). Neo-traditional Salafis in the West: Agents of (self)-exclusion. In S. Yasmeen, \& N. Markovic (Eds.), Muslim citizens in the West: Spaces and agents of inclusion and exclusion (pp. 125-142). Farnham, UK: Ashgate.

Durkheim, E. (1951). Suicide: A study in sociology. New York: The Free Press. (Original work published 1897)

Farzin, S. (2006). Inklusion/Exklusion. Entwicklung und Probleme einer systemtheoretischen Unterscheidung. Bielefeld, Germany: Transcript.

Frindte, W., Boehnke, K., Kreikenborn, H., \& Wagner, W. (2012). Lebenswelten junger Muslim in Deutschland. Berlin, Germany: Bundesministerium des Innern.

Frölund Thomsen, J. P. (2012). How does intergroup contact generate ethnic tolerance? The contact hypothesis in a Scandinavian context. Scandinavian Political Studies, 35(2), 159-178.

Gellner, E. (1994). Conditions of liberty: Civil society and its rivals. London, UK: Hamish Hamilton.

Granovetter, M. (1985). Economic action and social structure: The problem of embeddedness. American Journal of Sociology, 91(3), 481-510.

Inglehart, R., \& Norris, P. (2012). Muslim integration into western cultures: Between origins and destinations. Political Studies, 60(2), 228-251.

Kivisto, P. (2013). (Mis)Reading Muslims and multiculturalism. Social Inclusion, 1(2), 126-135.

Koopmans, R. (2015). Religious fundamentalism and hostility against out-groups: A comparison of Muslims and Christians in Western Europe. Journal of Ethnic and Migration Studies, 4(1), 33-57.

Kronauer, M. (2010). Exklusion. Die Gefährdung des Sozialen im hoch entwickelten Kapitalismus. Frankfurt am Main and New York: Campus.

Kühnel, S., \& Leibold, J. (2007). Islamophobie in der deutschen Bevölkerung: Ein neues Phänomen oder nur ein neuer Name? Ergebnisse von Bevölkerungsumfragen zur gruppenbezogenen Menschenfeindlichkeit 2003 bis 2005. In M. Wohlrab-Sahr \& L. Tezcan (Eds.), Soziale Welt. Konfliktfeld Islam in Europa (Sonderband 17, pp. 201-220). Baden-Baden: Nomos.

Lockwood, D. (1964). Social integration and system integration. In G. Zollschan \& W. Hirsch (Eds.), Explorations in social change (pp. 244-257). Boston, MA: Houghton Mifflin.

Lucius-Hoene, G. (2000). Constructing and reconstructing narrative identity. FQS Online. Retrieved from http://www.qualitative-

research.net/index.php/fqs/article/view/1087/2379

Lucius-Hoene, G., \& Deppermann, A. (2004). Rekonstruktion narrativer Identität. Ein Arbeitsbuch zur Analyse narrativer Interviews. Opladen, Germany: VS.

Luhmann, N. (1997). Die Gesellschaft der Gesellschaft.
Frankfurt am Main, Germany: Suhrkamp.

Marshall, T. H. (1950). Citizenship and social class, and other essays. Cambridge, UK: Cambridge University Press.

Miligan, S., Andersen, R., \& Brym, R. (2014). Assessing variation in tolerance in 23 Muslim-majority and Western Countries. Canadian Review of Sociology, 51(3), 239-261.

Modood, T., \& Ahmad, F. (2007). British Muslim perspectives on multiculturalism. Theory, Culture \& Society, 24(2), 187-213.

Narayan, D. (1999). Bonds and bridges. Social capital and poverty. New York: World Bank.

Nollert, M. (2010). Kreuzung sozialer Kreise. Auswirkungen und Wirkungsgeschichte. In C. Stegbauer \& R. Häußling (Eds.), Handbuch Netzwerkforschung (pp. 159-167). Wiesbaden, Germany: VS.

Nollert, M. (2014). Die integrative Kraft multipler Zugehörigkeiten und Identitäten. In M. Löw (Ed.), Vielfalt und Zusammenhalt. Verhandlungen des 36. Kongress der Deutschen Gesellschaft für Soziologie in Bochum und Dortmund 2012 (pp. 957-969). Frankfurt am Main, Germany: Campus.

Nollert, M., \& Sheikhzadegan, A. (2014). Vereine als Quelle von Identität und Toleranz. Narrativbiografische Interviews mit engagierten Muslimlnnen in der Schweiz. In K. B. Schnebel (Ed.), Europäische Minderheiten: Im Dilemma zwischen Selbstbestimmung und Integration (pp. 297-336). Wiesbaden, Germany: Springer VS.

Nollert, M., \& Sheikhzadegan, A. (2016). Kreuzung sozialer Kreise, multiple Identitäten und Toleranz: Eine Analyse zivilgesellschaftlich engagierter Musliminnen in der Schweiz. In M. Nollert \& A. Sheikhzadegan (Eds.), Gesellschaften zwischen Multi- und Transkulturalität (pp. 129-165). Zürich, Switzerland: Seismo Verlag.

Park, R. E. (1928). Human migration and the marginal man. American Journal of Sociology, 33(6), 881-893.

Pescosolido, B. A., \& Georgianna, S. (1989). Durkheim, suicide, and religion: Towards a network theory of suicide. American Sociological Review, 54(1), 33-48.

Putnam, R. (2000). Bowling alone: The collapse and revival of American community. New York: Simon \& Schuster.

Roccas, S., \& Brewer, M. B. (2002). Social identity complexity. Personality and Social Psychology Review, 6(2), 88-106.

Rudnev, M. (2013). Value adaption to a new social environment: Impacts from country of birth and country of residence on values of intra-European migrants (Working Papers, 13/SOC/2013). Moscow, Russia: National Research University Higher School of Economics

Schneider, G. (2002). Ungläubig sind immer die anderen. Weltreligionen zwischen Toleranz und Fanatismus. Stuttgart, Germany: Klett-Cotta. 
Sen, A. (2006). Identity and violence: The illusion of destiny. New York: W. W. Norton.

Sheridan, L. P. (2006). Islamophobia Pre- and PostSeptember 11th, 2001. Journal of Interpersonal Violence, 21(3), 317-336.

Simmel, G. (1908a). Die Kreuzung sozialer Kreise. In G. Simmel (Ed.), Soziologie. Untersuchungen über die Formen der Vergesellschaftung (pp. 305-344). Berlin, Germany: Duncker \& Humblot.

Simmel, G. (1908b). Exkurs über den Fremden. In G. Simmel (Ed.), Soziologie. Untersuchungen über die Formen der Vergesellschaftung (pp. 509-512). Berlin, Germany: Duncker \& Humblot.

Stichweh, R. (2005) Inklusion und Exklusion. Studien zur Gesellschaftstheorie. Bielefeld: Transcript.

Stolz, J. (2005). Explaining islamophobia: A test of four theories based on the case of a Swiss city. Schweizerische Zeitschrift für Soziologie, 31(3), 547-566.

Stonequist, E. V. (1961). The marginal man: A study in personality and cultural conflict. New York: Russell and Russell. (Original work published 1937)

Tausch, A. (2014a). Armut und Radikalität. Soziologische Perspektiven zur Integration der Muslime in Europa. Bremen, Germany: EHV AcademicPress.

Tausch, A. (2014b). Further insights into global and Arab Muslim opinion structures: Statistical reflections on the 2013 Pew report "The world's Muslims". Middle
East Review of International Affairs, 18(1), 8-24.

Tausch, A. (2015). Hofstede, Inglehart and beyond. New directions in empirical global value research. MPRA Paper No. 64282. Munich, Germany

Tausch, A., \& Karoui, H. (2011). Les musulmans: Un cauchemar ou une force pour l'Europe? Paris, France: L'Harmattan.

Van Oudenhoven, J. P., Prins, K. S., \& Buunk, B. P. (1998). Attitudes of minority and majority members towards adaptation of immigrants. European Journal of Social Psychology, 28(6), 995-1013.

Weber, M. (2002). The protestant ethic and the spirit of capitalism. Los Angeles: Roxbury. (Original work published 1905)

Welsch, W. (2009). Was ist eigentlich Transkulturalität? In L. Darowska \& C. Machold (Eds.), Hochschule als transkultureller Raum? Beiträge zu Kultur, Bildung und Differenz (pp. 39-66). Bielefeld, Germany: transcript.

Wohlrab-Sahr, M. (1999). Konversion zum Islam in Deutschland und den USA. Frankfurt am Main, Germany: Campus.

Yasmeen, S. (2014). The dynamics of exclusion/inclusion: Australia as a case study. In S. Yasmeen \& N. Markovic (Eds.), Muslim citizens in the West: Spaces and agents of inclusion and exclusion (pp. 15-32). Farnham, UK: Ashgate.

\section{About the Authors}

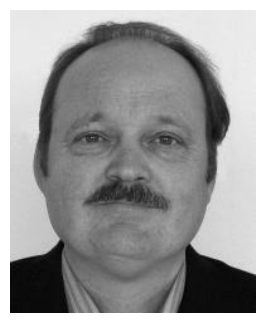

\section{Dr. Michael Nollert}

Michael Nollert is professor at the Department of Social Sciences of the University of Fribourg, division of Sociology, Social Policy and Social Work. His research focuses on social inequalities and social exclusion and the impact of policies on social stratification. He has analyzed inequalities in the world system, in Latin America, in the intergenerational reproduction of social status (social mobility regimes), in the reproduction of economic elites and in the gendered division of unpaid work. Two of his current research projects deal with transnational networks of Bulgarian migrants in Switzerland and civic engagement of Muslims in Switzerland.

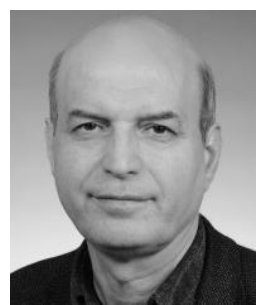

\section{Dr. Amir Sheikhzadegan}

Amir Sheikhzadegan, PhD in sociology from the University of Zurich, is a senior lecturer and researcher at the Department of Social Sciences of the University of Fribourg, division of Sociology, Social Policy and Social Work. He has been a visiting fellow at the "Zentrum Moderner Orient" (ZMO) in Berlin (DE) as well as at the "Religion and Society Research Cluster" of the Western Sydney University (AU). His fields of interest include Islam and modernity, Islam in Europe, minority-majority relations, multiculturalism, and civil society. 